\title{
Carlos Figueroa
}

Ithaca College

Politics Department

School of Humanities and Sciences

e-mail: cfigueroa@ithaca.edu

\section{U.S. Supreme Court in the civil rights era: Deliberative Democracy and its educative institutional role, 1950s-1970s"}

\begin{abstract}
This article examines the U.S. Supreme Court's lesser-known educative role as an egalitarian institution within a broader deliberative democratic process. Scholars have argued that the Court's long asserted power of judicial review, especially in the equal protection and civil rights context, has been an over-reach of the judicial branch's constitutional authority and responsibilities. Normative and empirical critiques have been centered on the aims of judicial review, and the challenges it poses in American political life. A core issue surrounding these critiques is that Justices are appointed not elected, and thus undermine the principle of majority rule in the U.S. constitutional democratic order. Although these critiques are legitimate in terms of claims about unelected Supreme Court Justices' seemingly discretionary powers over elected legislative bodies, and the uncertain policy implications of judicial pronouncements on the broader society, there is, nevertheless, a positive application of judicial review as a tool Justices use as part of their educative role overcoming the so-called "counter-majoritarian difficulty." Through a close reading of oral arguments in Brown vs. Board of Education (1954) and San Antonio vs. Rodriguez (1973) - two landmark cases invoking the Equal Protection Clause of the $14^{\text {th }}$ Amendment to the federal Constitution - the article shows how appointed Justices adjudicate individual cases on appeal and attempt to educate

\footnotetext{
* I first presented a version of this paper in 2005 at the Jacob Landynski Memorial Conference on Constitutionalism and Social Justice held at the New School for Social Research, New York City. I would like to thank the following people for their valuable feedback: Lucia Cardenas, Andrew Arato, Andy Polsky, K. E. Whittington, Patrick Macklem, Gwendolyn Alexis, Jennifer S. Breen, and Thomas Shevory.
} 
(through an argumentative, reason-based and question-centered process) citizenlitigants and their legal representatives about the importance of equality, fairness and ethical responsibility even prior to rendering final decisions on policy controversies that have broader national social, political and economic implications.

Keywords: educative court, deliberative democracy, judicial review, U.S. Supreme Court, ethical responsibility

JEL Classification: K4, N42

\section{Introduction}

Since the landmark case of Marbury v. Madison (1803), U.S. scholars have argued over when and how to justify the power of judicial review under a written Constitution that does not mention it (Rakove, 1990; Whittington, 2009). Alexander Bickel in 1968 warned that judicial review would lead to a "counter-majoritarian difficulty." He meant that when unelected judges reviewed and declared unconstitutional laws, policies or government actions by elected legislative bodies it would threaten the principle of majority rule at the heart of U.S. liberal democracy. Yet, Robert Dahl (1957) had already found an answer to this concern:

To consider the Supreme Court of the United States strictly as a legal institution is to underestimate its significance in the American Political System. For it is also a political institution, an institution, that is to say, for arriving at decisions on controversial questions of national policy. (p. 279)

Dahl's view has gained more wide support over the years (Voeten, 2014), while providing a more expansive understanding of the Court's constitutional functions. So, the guiding question is not so much regarding judicial review, but rather whether or not the Court at times educates at the adjudicative level within its more recognized multi-constitutional roles.

The question of whether the Court has an educative function has had scholarly interest since the mid-twentieth century (Epstein, Knight \& Martin, 2001, pp. 583587). Eugene V. Rostow (1952) used the metaphor "a vital national seminar" to describe what the Court was doing fundamentally in the 1950s civil rights context (p. 208), while Richard Funston (1978) claimed there had always been a Higher-law tradition in the United States — whether natural or provincial - where "mere statutory enactments must accord if they are to be legitimate" and where such a tradition was reduced to a written Constitution in the $18^{\text {th }}$ Century placing limits on government actions while "guaranteeing certain rights to the individual" (p. 13). He concluded that an "existence of a written [Constitution] presupposes a final arbiter," that is, the Court upholding the "will" of the people by serving as national teacher of democratic values through its legal pronouncements (p. 13). 
My aim in this article is to move beyond the arguments of whether or not judicial review serves U.S. constitutional politics. And, instead I explore the Court's educative role within a pluralist deliberative democracy (a broader reason-based and ethical process). Through a close reading of oral arguments in Brown vs. Board of Education (1954) and San Antonio vs. Rodriguez (1973) - two landmark cases invoking the Equal Protection Clause of the $14^{\text {th }}$ Amendment to the federal Constitution-the article shows how appointed Justices adjudicate individual cases on appeal and attempt to educate (through an argumentative, reason-based and question-centered process) citizen-litigants and their legal representatives about the importance of equality, fairness, and ethical responsibility even prior to rendering final decisions on policy controversies that have broader national social, political and economic implications.

\section{Employing judicial review in an ethically responsible way}

The concept of judicial review has informed the ways in which the U.S. courts, including the Supreme Court, have conducted its constitutional authority and ethical responsibilities since the Founding. Henry J. Abraham and Barbara A. Perry (2003) observe:

There was no unanimity as to who might arbitrate; and the records of the debates at the Constitutional Convention now available to us demonstrate that nearly every segment of the incipient governmental framework received at least some consideration for the role of arbiter: the states themselves, Congress, the executive, the judiciary, and several combinations of these. But it was fairly clear that the role would fall to the judiciary and that it should include the power of judicial review, which authorizes the Supreme Court to hold unconstitutional, and hence unenforceable, any law of official action based upon a law, and any other action by a public official that it deems - upon careful reflection and in line with the inherited tradition of the law and judicial restraint - to be in conflict with the Constitution. (pp. 3-4)

More presently, the concept of judicial review serves as an interpretive device for practicing judges allowing them "to consider and overturn any congressional and state legislation or other official governmental action deemed inconsistent with the Constitution, Bill of Rights, or federal law" (O'Brien, 2003, p. 23 ). Although judicial review is not explicitly stated in the written Constitution, nor are the principles of federalism, checks \& balances or the separation of powers, all are nonetheless implied in the structure of the document (Rakove, 1996, p. 175).

David M. O'Brien (2003) suggests the Constitution “amounts to a prescription for political struggle and an invitation for an ongoing debate about enduring constitutional principles" (p. 24). Yet, James B. Thayer (1893) previously found that judicial review had some historical precedent in the common law, and more importantly, in certain state constitutions at the time of the founding of the 
Republic (pp. 132-134). Thus, there are historical and constitutional sources supporting the concept and use of judicial review as a tool for judges within the American liberal democratic order.

Moreover, John H. Ely (1980) and Cass Sunstein (1993) provide separate normative arguments for the legitimate use of judicial review as part of a justice's constitutional duties. Ely reads the Constitution as principally a procedural document, which protects the notion of popular sovereignty via judges who serve as guardians of democracy. He claims the Court should police the politics behind policy-making and policy-outcomes in certain circumstances: a legislative action should be overturned as unconstitutional, if and only if, it results from a malfunctioning or a defective democratic process (pp. 100-104). By democratic process, Ely means legitimate representative politics, elected officials with an elected mandate decide on behalf of constituents. Similarly, Sunstein expects the Court to protect individual fundamental rights central to liberal democracy, such as free political speech. He requires significant judicial intervention to ensure the success of political reforms: the Court should take a more "skeptical" approach to classifications based on race, gender, sexual orientation, and poverty (p. 43). Consequently, Ely and Sunstein see unelected Justices as active agents who must partake in a deliberative process guiding political actions and outcomes rendering almost irrelevant Bickel's "counter-majoritarian difficulty" concerns. Therefore, judicial review from this broader standpoint, not only would support, but also enhance representative democracy, strengthen the policy development process, and safeguard citizen's fundamental rights and ethical values.

Bickel (1968) does agree that one federal branch of government ought to be the final arbiter and concedes this role to the Supreme Court. The "courts have certain capacities for dealing with matters of principle" he states, "that legislatures and executives do not possess" (p. 25). And that only "judges have, or should have, the leisure, the training, and the insulation to follow the ways of the scholar in pursuing the ends of government" (p. 26). This suggests that judges may possess the tools, skills, and abilities to carry out their important roles within the U.S. democratic order. Yet, Ely notes that Bickel shifted his support for the liberal theory of judicial review and became a strong critic instead because of the excesses of the Warren Court in the 1950s-1960s. (p. 71).

Still, Bickel claims that by interfering with the policy decisions of popularly elected representatives, the Court frustrates the majority's policy preferences. He argues,

Judicial review is a counter-majoritarian force in our system. [And] when the Supreme Court declares unconstitutional a legislative act or the action of an elected executive, it thwarts the will of the representatives of the actual people of the here and now; it exercises control, not in behalf of the prevailing majority, but against it. That, without mystic overtones, is what actually happens. It is an altogether different kettle of fish, and it is the reason the charge can be made that judicial review is undemocratic. (pp. 16-17) 
Bickel ignores the internal organization and structure of the legislative bodies, which often attenuate the relationship between popular preferences and legislative policy outcomes (e.g. federal or state statutes). He relies on an unstated assumption that we can identify and translate the people's preferences as an aggregate and read into legislative outcomes.

\section{National seminar metaphor: Making sense of the Court's educative role}

The "educative" institution inquiry is not new and thus has been pursued by several political scientists and public law scholars. On the one hand, Richard Funston (1978) claims that the Court teaches the American people by producing wellreasoned opinions about the "philosophic ramifications" of the popular branches" laws or acts (p. 217). Accordingly, he suggests the Court teaches as it accomplishes its constitutional function "as a legitimating institution, bringing the nation's short-run, expedient means into accord with its long-run ends or principles" (p. 217). On the other hand, Christopher Eisgruber (1962) offers that the Justices instead educate "not by propounding scholarly doctrines, but by offering ad hominem lessons capable of inspiring Americans to honor their values" (p. 961). Nevertheless, Funston and Eisgruber are not the only scholars to appropriate in one form or another Rostow's (1952) metaphor "a vital national seminar." Bickel and Gerald Rosenberg (1993) separately considered such a grand vision with the Supreme Court at the head of the table. Bickel (1968) states:

The educational institution that both takes the observation to correct the dead reckoning and makes it known is the voice of the Constitution: the Supreme Court exercising judicial review. The Justices, in Dean Rostow's phrase, "are inevitably teachers in a vital national seminar." No other branch [...] is nearly so well equipped to conduct one. And such a seminar can do great deal to keep our society from becoming so riven that no court will be able to save it. Of course, we have never quite been that society in which the spirit of moderation is so richly in flower that no court needs to save it. (Bickel, 1968, p. 26; Rostow, 1952, p. 208)

But simply to assert that Justices can be educators, as Bickel does and Rostow before him, leads to several important questions: To what extent are they teachers? What kind of teachers? And how does this supposed educational institutional role fit within an American democracy characterized as majoritarian? To reiterate an earlier point, the main contention about judicial review is that the Supreme Court's actions against elected legislative bodies are counter-majoritarian and therefore undemocratic. This objection rests on questionable if not weak assumptions: (1) that a majority of eligible voters do in fact elect their political representatives in a given election, or (2) that the preferences of citizens within the American democratic order are easily aggregated and thus made the "majority." 
According to the majoritarian premise, democracy is improved when it is designed to produce collective decisions that reflect majority preferences and consensus. This "counter-majoritarian" claim attempts to make sense of a presumed tension between judicial review and American democracy. Bickel (1968) offers an exception to his undemocratic claim that judicial review could be justified democratically speaking only if it adds something significant to government that is otherwise lacking (p. 58). Moreover, since the legislative process is unprincipled, the Court through judicial review should inject principles (or ethical values) into the American governmental system. But Bickel's point is premised on the Court's ability to promote such values through judicial opinions. Yet, I agree with Bickel about the Court's influence in the system. However, I think that the Court, as the evidence shows, might have a constitutional duty to guide others into affirming and adhering democratic rights and ethical values but prior to legal pronouncements. In this sense, political responsibilities include injecting ethical values during oral arguments but also upholding fundamental rights - equality, and fairness - as significant elements sustaining U.S. liberal-democracy life.

As for Rosenberg (1993), he provides a test of the "vital national seminar" thesis (p. 9) as he examines "whether and under what conditions, courts can produce significant social reform" (p. 336). Yet, his argument is anchored on the same underlying premise, relied on by Bickel, Funston and Eisgruber, that says an educative component to the Court's functions exists but as measured by the impact or compliance of legal pronouncements. However, Rosenberg is less concerned with the educative role than with assessing whether or not the Court is a catalyst for social change, or whether the Court has determinative power in American politics and society. Consequently, he explores what the Court ought to do and not what it really can do. He does conclude that the Court has been ineffective in producing social change or "policy change with nationwide impact" (1993, p. 4).

Although Rosenberg does not directly address the question regarding whether or how, if ever, the Court performs an educative role within the American political system, he does provide some hope:

If the Court was consequential in civil rights, then its influence should be identifiable and measurable. The more places in which it can be identified, the stronger the claim is. On the other hand, the fewer places in which it is found, the less likely it is that the effect of the Court is as powerful as the Dynamic Court view contends. (1993, p. 108)

Rosenberg (1993, p. 108) distinguishes between two views of the Court:

(1) Dynamic Court view - the Court protects minorities and defends liberty in the face of opposition from popular branches of government, fulfilling an important role within the American political order, and

(2) Constrained Court view-the Court lacks the power of the "sword or purse," the Court's ability to produce political or social change is limited, and can do little than point out how actions have fallen short of constitutional or legislative requirements and hope that appropriate action is taken. 
Rosenberg finds that "most Americans neither follow Supreme Court decisions nor understand the Court's constitutional role" (1993, p. 131). What he suggests then is for groups or individuals not to waste their resources on litigation, but rather they ought to engage in widespread mobilization as the only meaningful path to social change. Moreover, he asserts, "the combination of growing civil rights pressure from the 1930s, economic changes, the Cold War, population shifts, electoral concerns, and the increase in mass communication all created the pressure that led to civil rights. The Court reflected that pressure; it did not create it" (p. 169). In sum, Rosenberg provides a list of historical "causal" factors that may explain the civil rights movement, but does not give any credit to the Court for playing a pertinent role in such a movement. ${ }^{1}$

This failure I would submit (if we can correlate change with educating) arises from Rosenberg's focus on the impact of the Court's decisions, and not the lawmaking process itself. Still, it seems that Rosenberg leaves the door open for such a possibility:

Social scientists do not understand well enough the dynamics of influence and causation to state with certainty that the claims of Court influence (or any other causal claims) are right or wrong. Similarly, social scientists do not understand fully the myriad of factors that are involved in an individual's reaching a political decision. Ideas seem to have feet of their own, and tracking their footsteps is an imperfect science. Thus, even if I find little or no evidence of extra-judicial influence, it is simply impossible to state with certainty that the Court did not produce significant social reform in civil rights. (1993, p. 108)

Not surprisingly, Rosenberg believes that other forms of empirical analysis need to be conducted beyond social impact or institutional compliance studies, which are based on judicial opinions.

Recall that Funston (1978) did consider this issue within his "national seminar" metaphor and the Court's constitutional functions. I agree with him: if the ends of government is to be based on principle, then "some agency must, in the normal operations of the policy process, be concerned with society's fundamental, underlying values [...] that agency should be the Supreme Court, and in fact, in American politics, it can only be the Court" (Funston, 1978, p. 49). I also agree that through judicial review the Court may appeal to "the majority to take a sober second look at the course it has set for the nation," however not with how

\footnotetext{
${ }^{1}$ Rosenberg does highlight three constraints the Court must overcome, which may then lead to producing social reform: (1) The limited nature of constitutional rights; (2) The lack of judicial independence, and (3) The judiciary's lack of implementation power. He finds that when certain conditions are met, the Court can produce limited change: if it overcomes constraint (1), there is ample legal precedent for change; if it overcomes constraint (2), there is support for change from substantial members of Congress and the executive; and if it overcomes constraint (3), there is support from citizens (or at minimum low levels of opposition); along with one other condition from the following: when other actors offer incentives for compliance, when other actors impose costs to non-compliance, when implementation of opinions can be left to the private market, and when individuals crucial for implementation are seeking either political leverage or cover and are willing to act (1993, pp. 35-36).
} 
this should be done. Funston emphasizes the impact of the Court's educating practices as legitimating legislative policy outcomes since Justices are involved in a "gradual building of constitutional doctrine" (Funston, 1978, p. 51).

A difference emerges between Eisgruber, Funston and Rosenberg. Eisgruber (1962) introduces a different theoretical argument to the "educative institution" debate. His claim is that "the Supreme Court cannot be fully understood except as an institution with educative responsibilities, responsibilities that depend upon the excellence of its arguments" (p. 964). According to Eisgruber, the Court teaches ethical principles to the American people through its opinions, which leads to lessons that are ad hominem descriptions of American political identity. This identity leads to motivating action. Thus, "what distinguishes the Court as an educative institution," Eisgruber argues, "is not its knowledge of ethical theories; rather, it is the Court's understanding of its audience" (p. 985).

Eisgruber seems to rely on an implied assumption that either American values are universal and absolute, or that the American people are a sum of heterogeneous individuals but with similar goals in adhering to certain principles that comply with a fixed notion of liberal citizenship. This might be problematic in the same sense that democracy is said to be majoritarian. Moreover, his view of the Court seems elitist and at odds with an egalitarian perspective stating that the Court may not be the only but might be the most appropriate expounder of ethical values in U.S. political life, and thus shaper of identity, although it rarely teaches: "Indeed, the Supreme Court might be an essential source of explanations directed to American political identity even if the Court is neither the only nor the most prolific source" (1962, p. 989). I might agree with the infrequency of the educating role but not with such an isolated place for the Court since it would undermine its position as a "co-equal" institution in relation to the other two federal bodies. Nonetheless, Eisgruber provides a useful theoretical framework in which to check the Court's source of its educative role as a point of comparison: "The constitutional structure gives the Supreme Court both an incentive and an opportunity to supply educative descriptions of American identity" (p. 1004).

Although Eisgruber (1962) focuses on the impact of written opinions and how through such the Court teaches about key fundamental values and constitutional principles to the American people, which in turn motivates them towards taking ethical responsibilities seriously, I nonetheless disagree with his observation that empirically "the Court is exceptionally well-suited to produce essential lessons about ethical matters; but that [it] fails to do so, or that nobody listens when it does" (p. 1029). There is an important distinction between my views and both Funston and Eisgruber. They both proceed from the premise that judicial pronouncements are the catalyst, if not the source, of the Court's educative institutional role. I instead argue that what, and who is being taught and the how it is taught may be inherent in the where and when; that is, the Court's educative role, and the content of its teaching seem to manifest through oral arguments prior to the Court's legal pronouncements. Thus, oral argument proceedings may serve as 
the source of the Court's educative as well as reveal the substance being taught as the Justices attempt to resolve concrete constitutional disputes for those involved in the litigation but with far-reaching implications.

Now some may ask: How does a non-elected Court see itself as an educative institution? To answer this question, we need to reverse our tracks a bit before proceeding forward. As scholars we understand that in a republican form of government, a citizen's vote is used primarily to elect representatives to the legislatures (federal and state) and an executive (though not directly through the Electoral College), which themselves select judges whose role it is to ensure that the "government" does not violate fundamental rights and values as embodied in the Constitution and elsewhere or otherwise upset the basic agreements that underlie political institutions. This may sound dramatic but the whole point of an independent judiciary is to be "antidemocratic" in its institutional role (in a majoritarian democracy), in order to preserve from transient majorities those human individual rights and other principles to which an American Liberal-democratic order is committed. Without this there would be nothing to stop a bare majority of citizens from deciding that the minority should be for example "enslaved." This is of course moot in a pluralist democracy because of its various protective mechanisms. In other words, in order for such a scenario to occur empirically, we would have to lay aside the bicameral legislature, Senate filibuster, presidential veto, representative government, just to name a few.

\section{An alternative model: Pluralist deliberative democracy}

What does it mean for unelected judges to exist in a "co-equal" manner within a deliberative democratic order? Terri Perreti (1999) recognizes that Bickel and others ignored the possibility that judicial review is reconcilable with, and necessary to American democracy. She asserts that this problem "is due to their misguided view of American democracy as majoritarian, electorally controlled, and legislative centered" (pp. 229-230). Rather she submits that American democracy is better understood as pluralist.

Our political system is not directed to the goal of majority rule; it is in virtually all aspects an anti-majoritarian system, including its rejection of legislative supremacy. Rather, our system provides numerous and diverse political institutions, none of which is hierarchically superior to another, whether in theory or practice. The underlying purpose is to provide groups, especially minorities, with a variety of arenas in which to advance their interests and contest policies with which they disagree. Accordingly, denigrating the Court for interfering with the definitive and presumptively superior electoral and legislative determinations of political winners, at least in the context of pluralist politics, makes little sense. (Perreti, 1999, p. 229) 
In this pluralist system, judicial review is neither deviant nor illegitimate. Rather, it is a quite normal expression of the pluralist principles of redundancy and diversity in political representation. (Perreti, 1999, p. 230)

Perreti reorients the historical and theoretical debate on democracy making room for judicial review as the Court's initial form of democratic intervention. Accordingly, in order to support this "co-equal" institution claim (or institutional egalitarianism), we must characterize American democracy not as majoritarian but as pluralist. Hence, as a pluralist democracy, the American representative system becomes more inclusive, politically and socially balanced.

However, without a notion of deliberation, even a pluralist democratic government falls short of creating and maintaining political equality, fairness and liberty. Scholars have understood that "the success or failure of deliberation depends [...] on its context" (Thompson, 2008, p. 499), but also on the potential for diversity of political views and even ideological perspectives (Besson \& Marti, 2006).

Chantal Mouffe (2005) offers the following as a way to think about the connections between pluralism, social conflicts and democracy: "[A]gonistic [or an argumentative] confrontation is the [...] condition of [democracy's] existence [...] a pluralist $[. .$.$] democratic society does not deny the existence of conflicts but$ provides the institutions allowing them to be expressed in an adversarial form" (p. 30). Moreover, political and legal antagonisms are both inherent characteristics within diverse human social relations (Figueroa, 2014; Mouffe, 1999, p. 754). As such, the U.S. citizen, especially those seeking legal redress for political, social and economic issues, becomes more apt to perceive, and accept the Court's various roles within a pluralist deliberative democracy since it would serve as another institution open to discussion for resolving conflicts that are not adequately addressed by elected officials in coordinate branches.

Another way to consider deliberative democracy is as a process for communication where citizens "exchange reasons for their preferences, rather than solely voting on them [and these] individual preferences are not (pre-politically) fixed and might change as a result of collective deliberation, which also promises greater democratic legitimacy" (Marsh, Ercan \& Furlong, 2017, p. 195). So, at the center of deliberative democracy is the notion of "reason-giving", which means, in terms of the Court's power of review and educative role, that citizen-litigants and their lawyer-representatives in oral arguments "are expected to justify the laws [and values] they would impose [...] by giving reasons for their [legal] claims and responding to others' reasons in return" (p. 498). Marti (2017) says it best,

[Pluralism] and disagreement is not only pervasive and unavoidable in democratic, open societies, but also morally valuable. But pluralism is morally valuable because values are plural themselves and it is a necessary condition of lively, open democratic politics. What is more, disagreement must be seen as a "primary creative source of deliberation." (p. 563) 
Disagreements come in different forms, political, legislative, regulatory, constitutional and adjudicative, among others (Marti, 2017, p. 564). Thus, as I have been suggesting, this deliberative democratic process occurs not only in the ordinary political arena, but also in legal spaces, in particular the Supreme Court as a "co-equal" institution during oral arguments.

However, when constitutional meaning is contested and fundamental rights seemed undermined, why does a "co-equal" Court get to "say what the law is" and trump the constitutional understandings of the other branches? In what sense is the Court speaking for the "will" of the people in such cases of interpretative or political uncertainty? To these questions, Supreme Court Justice William J. Brennan, Jr. (1972) commented:

The Justices are charged with deciding according to law. Because the issues arise in the framework of concrete litigation they must be decided on facts embalmed in a record made by some lower court or administrative agency. And while the Justices may and do consult history and the other disciplines as aids to constitutional decision, the text of the Constitution and relevant precedents dealing with that text are their primary tools. (p. 38)

Justice Brennan, Jr. proposes that the constitutional duty Justices have is critically important to the democratic experience overall. So the important notion is "concreteness" where the Court does its work at the level of appellate reviews in which oral argument is heard, competing interpretations of constitutional provisions are debated, and citizens' fundamental democratic rights and values are clarified and shaped but with the Constitution as the guiding force in the process. This is where the people's "will" is present throughout the process.

To be clear, I am not suggesting the Court-in implying institutional egalitarianism through the assertion of judicial review - is undermining the importance of other political institutions. Rather, if we characterize American democracy as pluralist and deliberative, then the Court has a legitimate "co-equal" institutional responsibility to protect the people's "will" by focusing first on the individual litigants and subsequently on protecting the integrity of the whole system and its fundamental values. This would once again raise the judicial supremacy objection, as Bickel (1968) states, "judicial review is a deviant institution in the American democracy" (p. 18). Nevertheless, I argue rather that its "co-equal" status, under a pluralist deliberative democracy, is best understood in terms of the Court advancing liberal-democratic values - equality, fairness and ethical responsibilitywithin its educative capabilities during oral arguments.

\section{Foundations of Court's "co-equal" institutional status}

We can trace the source of the "co-equal" institutional status argument-in the context of civil rights and liberties - to footnote 4 in United States v. Carolene Products (304 U.S. 144 [1938]). Footnote 4 appeared one year after the Supreme 
Court abandoned its previous laissez faire position in defense of the economic rights of businesses and employers. Typically in such cases, the Court had applied "strict scrutiny" judicial review ${ }^{2}$ on legislation affecting property rights to determine whether it served a legitimate public purpose and was reasonable in its terms. Most importantly before 1937, the Court was hostile to congressional attempts to intervene in the private sphere to protect farmers, laborers, children and other vulnerable groups (Abraham, 2003, pp. 91-93; O’Brien, 2003, pp. 13091310). In footnote 4, Justice Stone recognized a need to acknowledge and focus on the "will" of the ordinary people. As Davis and Graham (1995) state,

A novel jurisprudence was in its embryonic stage of development, and racial and ethnic minorities would be its recipients. A legal weapon had been devised that would transform the constitutional order in the area of civil liberties. The constitutional significance of footnote 4 lies in its justification for a higher degree of scrutiny, or strict scrutiny, against legislation that discriminates against discrete and insular minorities. (p. 77)

The Court seems to serve multiple functions-legal, political and educative-when it protects individual liberties, societal values and overall fundamental rights as a democratic guardian to the people (Goldstein, 1987, pp. 391, 402-403), while not over-estimating its egalitarian institutional implied powers within the pluralist constitutional system in which it finds itself.

Jacob W. Landynski (1982) shows the significance of the Court's use of judicial review as part of a necessary element to engaging in deliberative democratic practices as a "co-equal" institution.

Ordinarily the political system is adequate to defend individual liberties. When it is not, the Court's role must be redefined to allow broader judicial review as a substitute for the political review which [vulnerable minority] groups were unable to effectively to obtain. In effect, the Court appoints itself a surrogate legislature, judicially awarding the legislative bargains it believes these groups would themselves have struck were they politically influential. In such circumstances, judicial activism becomes defensible as a safeguard for democratic principles, for the Court can be seen as aiding democracy rather than blocking it; as giving expression to the political process rather than negating it. (pp. 37-38)

Landynski's eloquent statement reflects similar thoughts by Chief Justice Earl Warren who, in 1968, stated that the Supreme Court had the political and perhaps ethical responsibility to "always stand ready to advance the rights of [...] minorities, if the executive and legislative branches falter" (The Philadelphia Inquirer, p. 1). Both Landynski and Warren point to the importance of Justice Stone's footnote 4 to American political and constitutional development. Stone's

\footnotetext{
${ }^{2}$ The Court applies different levels — strict scrutiny, intermediate to rational - in order to determine the constitutionality of a law. Cf. http://law2.umkc.edu/faculty/projects/ftrials/conlaw/epcscrutiny.htm
} 
seemingly innocuous statement eventually led to the Court's shift towards protecting civil rights and liberties of political and social minorities by the mid-twentieth Century. ${ }^{3}$

\section{Supreme Court in brief historical context through the 1950s-1970s}

We know that "successful democracies tend to qualify the central principle of majority rule in order to protect minority rights" (Schmitter \& Lynn Karl, 1996, p. 53) and American democracy is no different in a situation where the Jim Crow ${ }^{4}$ segregationist regime (government mandated segregated public facilities for whites and blacks) continued to violate the constitutional rights of black American citizens and others immediately after the Civil War and even after the Reconstruction Amendments $\left(13^{\text {th }}, 14^{\text {th }} \& 15^{\text {th }}\right)$ were implemented. Adolph Reed, Jr. (2004) argues that this majority rule qualification extended through the 1960s:

The segregationist regime in the South encompassed far more than the "separate but equal" doctrine that Brown overturned in public education, far more than the petty apartheid reflected in Whites Only or Colored Only signs. It was a codified social order, a system of state-sponsored and state-enforced racial domination. It wasn't about prejudice and bigotry. Though it certainly fed on and legitimized both, it was fundamentally about who could claim the rights and protections of citizenship and who couldn't. And it was always at least as much about imposing and stabilizing a pattern of social relations rooted in the political economy's class and power dynamics as it was about formal commitment to an ideology of white supremacy.

It was also finite. It was the expression of reactionary elite's victory in the nearly thirty-year struggle over the terms on which a post-slavery Southern social order would be built. The Jim Crow regime sanctified in the infamous Plessy doctrine was only fully consolidated between 1890 and 1910. Its institutional back was broken by 1965 . That is, all four of my grandparents were at least adolescents by the time the system was solidly entrenched; its legal foundations were destroyed before I was old enough to vote.

Brown was both illustration of and impetus for that change. It was also a culmination of decades of careful strategizing and organizing, of protracted legal

\footnotetext{
${ }^{3}$ On this critical historical point, Louis Fisher (1999) states, "In 1938, at a time when the Supreme Court was withdrawing its scrutiny of economic regulation, Justice Stone wrote a footnote indicating that the court had a special obligation to protect minority rights. Justice Stone's formulation later evolved into "strict scrutiny" analysis for protecting fundamental rights, including issues of race discrimination and other concerns about the category of race, as Brown would subsequently demonstrate" (p. 874).

${ }^{4}$ For more on Jim Crow character, cf. https://www.ferris.edu/HTMLS/news/jimcrow/who/index.htm.
} 
struggle, against one facet of the segregationist order-a point where its separate-but-equal sophistry was most vulnerable —led by the NAACP and its allies. ${ }^{5}$

After the Court's 1937 shift towards protecting insular minority rights, justices mostly adhered to their constitutional obligations, and ethical commitments in advancing social change challenging Jim Crow laws that undermined liberal democratic values, i.e. freedom and equality.

During the early 1950s through the mid-1970s, the Court focused on protecting the civil rights and liberties of various minority groups, and enhancing equality norms and ethical standards by relying on the Equal Protection Clause of the $14^{\text {th }}$ Amendment to the federal Constitution (Araiza, Haddon \& Roberts, 2006, pp. 803805, 888-908; Fisher, 1999, pp. 874-898, 1024-1028). Moreover, the Court in this period of intense struggles against racial, class and gender discrimination-where legally sanctioned Jim Crow activities were entrenched in the American South and more subtle in the North - at times provided, although in somewhat tangential ways, instruction to Americans on the importance of liberal democratic life.

Two questions arise at this point that need to be addressed: How does the Court educate the American people about fundamental liberal values? And how does an educative Court serve democracy? I argue the Court often serves democracy when it grants appeals, hears oral arguments, and pronounces law in order to uphold the integrity of the democratic order. Although the Court may have failed to do so in the San Antonio case as discussed later. Nevertheless, Justice Felix Frankfurter, who was a proponent of judicial restraint ${ }^{6}$ (Frisch \& Stevens, 1973, p. 337), suggested that judicial review, in the case of Brown, at times served society as a whole, especially when the Court corrects the wrongs of elected legislative bodies.

The Court does its duty if it gets effectively under way the righting of a wrong. When the wrong is deeply rooted state policy the court does its duty if it decrees measures that reverse the direction of the unconstitutional policy so as to uproot it "with all deliberate speed." (O'Brien, 2003, p. 1390; Levinson, 2000, p. 149)

Yet, Justice Frankfurter's point could also extend to the Court providing a solid foundation for an implicit "co-equal" educator institutional role, regardless of ideological or even philosophical commitments.

David O'Brien (2003) rightly suggested that the last phrase pronounced in Brown II "with all deliberate speed" symbolized the Court's ethical appeal and adherence to the "will of the people" as a "co-equal" institution (p. 1390). In its role, the Court confronts, explores, and tries to make sense of the social, political and economic issues raised in appeal, especially if the legislative branch or lower courts only provide cursory treatment of these issues. This latter responsibility

\footnotetext{
${ }^{5} \mathrm{Cf}$. https://www.thenation.com/article/beyond-black-white-and-brown/.

${ }^{6}$ The theory that says judges should limit the use of their own powers of interpretation, and rather defer to the concrete constitutional issues before them and strict reading of the law. More on judicial restraint, cf. https://www.britannica.com/topic/judicial-restraint.
} 
begins when the Court grants appellate reviews, and then schedules oral arguments, or what I call "national seminars for democratic education."

To this end, the Court has also evolved over the years into setting the political and social agenda from within the internal adjudication process. For instance, historically the Court has indicated which kinds of cases and issues are worthy of judicial review. Sanford Levinson (2000), comments in the context of the activist Warren Court of the 1950s-1960s, for example:

It is not so much that the Supreme Court had taken on a dramatically new roleits primary concern at this period continued to be civil liberties and civil rightsas that it displayed a willingness to confront a host of important issues head-on and become, in important ways, a significant agenda settler for domestic policy. (p. 150)

However, why should we be more attentive to oral arguments since only a few people are involved in them and even less hears them? These arguments are not as public as other political events (e.g. congressional hearings, legislative debates in Congress, or judicial opinions), and thus, lack the audience necessary for any significant impact or educating for that matter? Why are public education cases - one on school segregation and the other on distribution of public revenue - good test cases for exploring the Court's educative role? The oral arguments are primary sources in which an "educative" element is most inherent in the way I have suggested. The assumption is that the Supreme Court educates during oral argument since traditional legal training is rooted in the Socratic Method in which questions are used for teaching and learning, and thus Justices employ this educating form in their attempts to resolve constitutional disputes on appeal. Moreover, during oral argument we find the intersection of several key constituents within American society: the ordinary citizen (litigant), the agent or representative of aggrieved individual (legal counsel), the arbiter (Justices), the select media, and general public (gallery). With respect to the cases selected, the Brown case focuses on discrimination against racial minorities and San Antonio case mostly on discrimination against the poor and their fundamental rights as citizens. Last, we know that historically racial and economic justice in the context of citizenship and constitutional laws have defined U.S. life since the Founding of the republic (Smith, 1997; Zinn, 1995). These two cases are linked together by a common constitutional thread: the Equal Protection Clause of the $14^{\text {th }}$ Amendment in the context of public education.

The Court's ethical responsibilities are "to define and vindicate rights guaranteed by Constitution, to assure uniformity of federal law, and to maintain constitutional distribution of powers in our federal Union" (Report of the Study Group, 1972, pp. 573, 578). To this extent, I have been arguing that within the Court's constitutional duties rest an educative function-as reflected in some oral arguments where participants deal with various levels of "disagreements" in deliberative fashion. Justices know that they have an adjudicative responsibility to explain their decisions to the American public and so use the oral argument, which precede such written explanation as a space to instruct, interrogate and guide those 
involved in the appeals process directly and others interested in such proceeding (i.e., media, and others for predictive purposes).

Yet, we need to remind ourselves that in regards to the oral argument, the Supreme Court does have some institutional constraints when providing "educative" interventions. "Judicial intervention is permissible when legislative or executive actions clearly violate specific constitutional prohibitions (e.g. the Bill of Rights)" (Keynes, 1991, p. 65). There may be two notions of such interventions:

(1) A process in which the Court takes an activist approach to constitutional interpretation,

(2) A process by which Justices pose different types of questions during oral arguments - to guide, instruct, and clarify various concepts, categories, values, principles and rights.

The latter notion is most important at present because it points to how the Court deals with concrete constitutional disputes that not only have personal short-term implications but also larger long-term resonance in reference to democracy as a value.

\section{Supreme Court's educative role within a pluralist deliberative democracy}

In this section, I examine the Court's "educative" role by interpreting portions of oral arguments in Brown v. Board of Education (1954), and San Antonio v. Rodriguez (1973). ${ }^{8}$ It is important to look closely at how the Justices themselves use linguistic techniques, rhetorical devices and pose probing value-laden questions during these deliberations. Questions are essential to the Court's ethically based educative role. David A. Hollinger finds that general discourse in our society, and the questions that informs it, are central to how and why individuals resolve communal disputes at any level. "Questions are the points of contact between minds, where agreements are consolidated and where differences are acknowledged and dealt with; questions are the dynamisms whereby membership in a community of discourse is established, renewed, and sometimes terminated" (Hollinger, 1979, p. 43).

Historically, Justices have had to maintain at least five assumptions in performing their educative roles (Hugh, 2002, p. 16):

(1) that the American people expect laws to be clear and easily understood,

(2) that the laws reflect the choices made by those who write and shape such laws while respecting the principle of popular sovereignty, and liberal values of fairness, equality and individualism,

\footnotetext{
7347 U.S. 483 (1954) argued December 9, 1952 and reargued on December 9, 1953 and decided on May 17,1954 by a 9 to 0 vote. Brown II, re-argument on the question of relief (remedies) from April 11-14, 1954 and decided on May 31, 1955 by a 9 to 0 vote.

${ }^{8} 411$ U.S. 1 (1973), argued October 12, 1972 and decided on March 21, 1973 by a 5 to 4 vote reversing lower federal District Court decision.
} 
(3) that the American people expect the laws to be consistent, stable, and predictable,

(4) that the laws "conform to the settled expectations of society" and "contribute to societal coherence," and

(5) that the American people expect the laws "to be flexible enough to adapt to a changing society, so that it may reflect contemporary notions of justice."

These guide Justices as they maintain a general constitutional balancing act while resolving concrete disputes on appeal, in particular during oral argument.

\subsection{Brown vs. Board of Education (1952-1955)}

The oral arguments in Brown took place between December 1952 and April 1955. There were ten oral arguments in total: In 1952, there were three, held December 9-11; in 1953, there were also three, December 7-9; and in 1955, there were four, April 11-14. These arguments show the Court guiding, interrogating, and instructing the parties before them in its attempts to deal with the issue of racial segregation in public education and illuminating the importance of equality, fairness and justice in democratic life.

In 1952, the Court heard oral arguments for the first time in the case of Brown. The appellants (those representing the elementary school children) and appellees (the Board of Education representatives) presented their respective arguments where the Plessy doctrine of "separate-but-equal" and the notion of "diversity in society" guided deliberations from the start. Brown I was really an amalgamation of several cases originating in four different states - Kansas, South Carolina, Virginia, and Delaware. The legal question was whether segregation of children in public schools solely on the basis of race, even though the physical facilities and other "tangible" factors may be equal, deprived children of a racial minority group of equal education opportunities. The appellants (Brown) contended that segregated public schools were not equal and cannot be made equal. This inequality fundamentally deprived "Negro race children" the equal protection of the laws. On the other hand, the appellees (Board) sought to persuade the Court to uphold the lower court's conclusion that the tangibles were equal although the public elementary schools were segregated by race. Thus, the appellees did not want the Court to pursue a direct attack on the Plessy doctrine of "separate-butequal."

In regards to the adoption of the $14^{\text {th }}$ Amendment and the later Plessy doctrine, the Court claimed, "We cannot turn the clock back to 1868 when the $\left[14^{\text {th }}\right]$ Amendment was adopted, or even to 1896 when Plessy was written. Must consider public education in the light of its full development and its present place in

\footnotetext{
${ }^{9} 163$ U.S. 537. The Court held that a Louisiana statute providing for separate but equal accommodations on railroads for Negroes and whites did not violate the Constitution. This law was subsequently cited as the source of the "separate but equal" doctrine.
} 
American life throughout the Nation" (p. 487). Despite appellees' plea for original intent - when judges seek textual meaning based on what the Constitution's framers intended (Powell, 1985) — during the oral argument, the Justices also considered the present 1950s status of public education. Chief Justice Earl Warren writes:

Today, education is perhaps the most important function of state and local governments. Compulsory school attendance laws and the great expenditures for education both demonstrate our recognition of the importance of education to our democratic society. It is required in the performance of our most basic public responsibilities [...] It is the very foundation of good citizenship. Today it is a principal instrument in awakening the child to cultural values, in preparing him [her] for later professional training, and in helping him to adjust normally to his environment. In these days, it is doubtful that any child may reasonably be expected to succeed in life if he [she] is denied the opportunity of an education. Such an opportunity, where the state has undertaken to provide it, is a right, which must be made available to all on equal terms. ${ }^{10}$

This well-articulated ethically grounded statement suggests an adherence to the Court's implied educative function mandated by the social and political circumstances of the time. This view on equality and fairness was not shared in the San Antonio case, however.

We see one example of the Court's educative role in the following exchange. During opening arguments on December 9, 1952, Mr. Robert L. Carter, Assistant Counsel to NAACP (legal-representative of the appellants) was speaking until Justice Harold H. Burton intervened:

Justice BuRTON: It is your position that there is a great deal more to the educational process even in the elementary school than what you read in the books? (Friedman, 1969, p. 17)

This query led Mr. Carter to confirm his position regarding the intangibles involved in education, and how these apply to the equal protection clause, and broader issue of social equality.

Mr. CARTER: Yes, sir. We say that the question of your physical facilities is not enough. The Constitution does not, in terms of protecting, giving equal protection of the laws with regard to equal education opportunities, does not stop with the fact that you have equal physical facilities, but it covers the whole educational process. (Friedman, 1969, p. 17)

\footnotetext{
${ }^{10}$ The Brown case. https://www.law.cornell.edu/supremecourt/text/347/483
} 
Carter thus argued that the Plessy doctrine was not controlling because of different facts presented in their current case, and reasoned that the state's sanctioned racial classification structure (one category requiring strict scrutiny ${ }^{11}$ by the Court), for the purpose of public elementary education fundamentally, violated the equal protection of the laws.

Mr. CARTER: It is our position that Plessy is not in point here; that it had nothing to do with educational opportunities whatsoever. We further take the position that whatever the court below may have felt about the reach of the Plessy case that this Court in the Sweatt case made it absolutely clear that Plessy had nothing to do with the question of education. (Friedman, 1969, p. 18)

Justice Burton's initial question attempting to seek clarification afforded Carter the chance to elaborate further on his position. This deliberative exchange shows some of the Court's educative character as Justices guided legal counsel towards recognizing constitutional precedents even at the expense of the latter's overall position. As Justice Felix Frankfurter's intervening question displays.

JUSTICE FRANKFURTER: The more specific question I would like to put to you is this: Do we not have to face the fact that what you are challenging is something that was written into the public law and adjudications of courts, including this Court, by a large body of decisions and, therefore, the question arises whether, and under what circumstances, this Court should now upset so long a course of decisions? (Friedman, 1969, p. 20)

In oral argument, legal counsel must respond to Court questions by referring to their overall position, especially as found in the previously submitted appellate briefs. Though, it can be said that the Justices with this type of intervention seem to indirectly instruct by providing evidence of customary Court's practices for guiding the line of debate towards a certain preferred outcome. Justice Frankfurter continues:

Justice FRANKFURTER: You are quite right in suggesting that this question explicitly as to segregation in the primary grades has not been adjudicated by this Court [...] but I do think we have to face in this case the fact that we are dealing with a long-established historical practice by the states, and the assumption of the exercise of power which not only was written on the statute books, but has been confirmed and adjudicated by state courts, as well as by the expressions of this Court. (Friedman, 1969, p. 21)

\footnotetext{
${ }^{11}$ The Equal Protection Clause of the $14^{\text {th }}$ Amendment is designed to prevent discrimination against certain classes of people. This is done when the Supreme Court applies different levels - strict scrutiny, intermediate to rational - in order to determine the constitutionality of a law. Cf. http://law2.umkc.edu/ faculty/projects/ftrials/conlaw/epcscrutiny.htm
} 
Justice Frankfurter through his inquiry and statement seems to take a subtle educative posture offering implicitly a lesson about up-holding legal precedent and historical practice. Carter is thus prompted to consider an alternative point of view, if not confirming his own position, in dealing with concrete issues, but also with the understanding that larger ethical, social, political and economic effects are at stake.

Accordingly, Carter feels obligated to move toward more transparency; he raises the social inequality issue that had been in the public discourse at the time, by challenging more directly Plessy's 'separate but equal' doctrine:

MR. CARTER: I have no hesitancy in saying to the Court that if they do not agree that the decision can be handed down in our favor on this basis [...] that I have no hesitancy in saying that the issue of "separate but equal" should be faced and ought to be faced, and that in our view the 'separate but equal' doctrine should be overruled. (Friedman, 1969, p. 21)

So, the equality issue moves away from tangible factors and into a reconsideration of the Plessy doctrine of "separate but equal." Carter wanted to know whether or not this doctrine applied. The question whether Plessy was good law was not addressed immediately, however. Instead, the Court takes control of the deliberative process facilitating the internal educational seminar (p. 22):

JUSTICE FRANKFURTER: Are you saying that we can say that "separate but equal" is not a doctrine that is relevant at the primary school level? Is that what you are saying?

MR. CARTER: Because in so far as this Court is concerned, as I have indicated before, this Court, with the exception of Gong Lum, has not at the elementary level adopted that "separate but equal" doctrine. There is no decision in this Court, unless the Court feels that Gong Lum v. Rice is that decision. As I attempted to indicate before, that was a case of first impression, although the Court did not seem to think it was, and that here actually we are now being presented - the Court is now being presented - with a case of first impression, when it has a full record, which you can give full consideration to, and that Gong Lum, which did not squarely raise the issue, ought not to be controlling. All I am saying is that you do not have to overrule "separate but equal" at the elementary school level in deciding the Kansas case because you have never decided the 'separate but equal' applied at the elementary school level.

JUSTICE DOUGLASS: I think you are saying that segregation may be all right in streetcars and railroad cars and restaurants, but that is all that we have decided.

MR. CARTER: That is the only place that you have decided that it is all right.

JUSTICE DOUGLASS: And that education is different, education is different from that?

MR. CARTER: Yes, sir.

JUSTICE Douglass: That is your agreement, is it not? Isn't that your argument in this case?

MR. CARTER: Yes. 
The Justices with these inquiries and comments provide guidance, cues and clarification to legal positions, but also suggest possible challenges to certain constitutional doctrines (i.e., "separate-but-equal") threatening at least two fundamental values, equality and liberty, to the extent that intangibles are also significant to the public school environment.

At the end of oral arguments, Chief Justice Warren concluded in Brown I, that 'in the field of public education the doctrine of 'separate but equal' has no place [and that separate] educational facilities are inherently unequal" (Landynski, 1983 , p. 257). Also Brown II was a re-argument largely devoted to the sociohistorical circumstances surrounding the origins of the $14^{\text {th }}$ Amendment, including the Equal Protection Clause. It covered extensively Congress's deliberations regarding the $14^{\text {th }}$ Amendment, ratification by the states, and then existing practices in racial segregation and finally the views of the proponents and opponents of the Amendments, respectively.

Finally, the Court concluded that although this information shed some light on the dispute at hand, it was not sufficient to resolve the problem. The Court stated, "At best," the historic evidence was "inconclusive." In the fall of 1955, the Court announced its second ruling calling for implementation of the 1954 decision "with all deliberate speed" but without setting a timetable for such a process (Brinkley, 1993, p. 789; Friedman, 1969, p. 535). It probably seems likely that the adjudicating process, and subsequent legal outcome, provided the necessary fuel for the NAACP and the rest of the civil rights movement to continue challenging state laws rooted in racial classifications that violated constitutional law throughout the 1950s, 1960s and 1970s. In another educative moment, Justice Brennan said it best in Brown that the Court has the constitutional and ethical responsibility to find a balance between upholding democratic ideals (and protecting all citizens), and taking serious account of the rapid complex changing social realities: "The claim of the Negro citizen [...] present a "conflict between the ideal of liberty and equality expressed in the Declaration of Independence, on the one hand, and, on the other hand, a way of life rooted in the customs of many of our people" " (Friedman, 1969, p. 39).

\subsection{San Antonio Independent School District v. Rodriguez (1973)}

In San Antonio v. Rodriguez, the Court considered the issue of equality from a different perspective. The Equal Protection Clause of the $14^{\text {th }}$ Amendment was again central within the context of public education. Yet, this case was less about race and more about proper resource distribution, neighborhood wealth and quality schooling; in particular, whether or not the $14^{\text {th }}$ Amendment's Equal Protection Clause requires states to provide equal funding for schools in rich and poor districts, measured by property values? A Texas statute appropriated funds to provide each child with a minimum education and local school districts matched it with funds from locally levied "ad valorem" property taxes. ${ }^{12}$ "Because the value of

\footnotetext{
${ }^{12}$ Ad valorem property taxes are those established in proportion to the value of the property to be taxed.
} 
taxable property as well as the number of school-aged children differed greatly among the state's more than one thousand districts, significant inter-district disparities existed in available enhancement revenues, per-pupil expenditures, and tax rates" (Gambitta, 1992, p. 753). The Federal District Court held that the Texas law_or method used for funding schools — deprived plaintiffs (appellees) their right to equal protection under the Constitution. Accordingly, this lower federal court "ordered the state to finance its schools so that the amount spent on a child's education did not depend upon the wealth of the neighborhood in which the child resided" (p. 754).

In 1973, the Supreme Court by a contested 5 to 4 vote reversed the lower District Court's decision that found the Texas school finance system unconstitutional because: (1) wealth was seen as a "suspect" category within the judicial review classification scheme needing protection, (2) education was considered a fundamental right also needing protection, and (3) Texas failed to demonstrate a "compelling interest" to justify its school funding system. Supreme Court Justice Powell, for the majority, and after a lengthy technical discussion about equality in public schools, proclaimed that education was not a fundamental right because it was not guaranteed either explicitly or implicitly in the Constitution. Essentially the Court concluded that there is no constitutional right to an equal educational opportunity. Moreover, that "wealth [was] not a suspect classification, and [also] that the state's system of funding public education was rational and constitutional" (O'Brien, 2003, p. 1532). What turned this case was that "Texas did not [...] deprive any class or anyone of an education, but rather assured [...] each child [...] receive a free minimum education" (Gamibitta, 1992, p. 754). Thus, instead of applying the strict scrutiny review test as the lower court had done, the Supreme Court applied the rational basis test (or minimal scrutiny) because the Texas school finance system did not disadvantage any Court recognized suspect classification, for example, race. As such, the Court concluded that Texas' method of public school finance did not violate the Equal Protection Clause of the $14^{\text {th }}$ Amendment since the state included local choices over tax rates, and a degree of educational enrichment that was seen as: (1) enhancing the state's legitimate interest in fostering local participation in public education, and (2) providing every child in the state with a free basic education (Gammon, 1977).

However, the dissenting Justices argued that the Texas statute departed from the state's purported objective of local control since property-poor school districts had no meaningful enhancement options available to them. Justice Brennan contended that a fundamental right to education did in fact exist because of education's importance to the enjoyment of rights that are guaranteed in the Constitution (a notion similar to Chief Justice Warren's ethical statement offered in Brown); and Justice Marshall followed that there ought to be a variable Equal Protection standard - one that assessed the characteristics of the class and the importance of the governmental benefits to that class-relative to the government's interest in retaining the class classification. 
With this outcome in mind, I explore several portions of the oral arguments in San Antonio dealing with the issue of equality, and fundamental rights and liberties. Mr. Charles A. Wright for the state of Texas and not School district, which ironically switched sides on appeal (Guitton \& Irons, 1993, p. 323), argued that the Texas system of public school financing although not perfect "does allow for local variety, experimentation, and independence [and] that is its goal that is its rationale" (The Supreme Court of the United States, p. 572). Because of this reason, he further claimed, "the rational basis test is the appropriate test" to be applied (p. 572). Thus, Wright sought a reversal of the lower Federal District Court's ruling by suggesting a different standard of judicial review be considered by the Court. A deliberation ensued regarding a proposed alternative system described as "district power equalizing" to which Wright was questioned whether he thought it would be appropriate to reach the constitutional standard of fundamental equality required:

JUSTICE WHITE: So there would still be an equal import—-there could be —into that? ${ }^{13}$

MR. WRIGHT: There certainly could be. In fact a whole reason for having district power equalizing would be to make unequal input possible.

Justice White: But under the Texas system it is impossible for some districts to have a sufficient input even if they are willing to tax themselves more.

This brief exchange beginning with Justice White's question provides, at minimum, an educative moment but for whom? The next exchange seems to suggest an answer:

MR. WRIGHT: To have a "sufficient input"? Was that your word, Justice White?

Justice White: Yes.

MR. WRIGHT: I would not agree with that, sir, no. Because our State Foundation program has assured to every district a sufficient input for an adequate education, and that it has left every district to decide for itself what, if anything, more-

Justice White intervenes as in an educational seminar facilitating and controlling the discussion while attempting to get clarification on some key aspects of the broader argument about the power equalization alternative system.

JUSTICE White: So you think this is really power equalization you have now?

Mr. Wright: No, I don't think that ours is power equalization. I think that ours is a matter of local choice.

\footnotetext{
${ }^{13}$ This question refers to a comment made by Justice Wright that "if district power equalizing is a viable alternative that this case has ceased to be a case about education at all [...] this becomes a case for the relief of taxpayers, rather than a case to help out school children. Many of the writers who support drastic reform, and who support reform as a matter of constitutional judgment, have said that the district power of equalizing solution would itself be unconstitutional because it would make the number of dollars spent on a child dependent on what friends and neighbors think" (The Supreme Court of the United States, p. 573).
} 
The Court begins to shift the conversation to the constitutionality of the Texas system more directly. Consequently, taking center stage is the notion of equal protection-as Justices Burger, Stewart, and Brennan intercede in the deliberative process.

Chief Justice Burger: Is there a question, however, that once the state understates to furnish education, then it must furnish a certain minimum adequate education for everybody? Once they start to go down that row they must follow through?

Justice Burger clearly emphasizes the social injustice of inequality as a fundamental value to consider.

Mr. WRIGHT: We certainly must do it for everybody, yes. If we are going to do it for any, then we must do it for every young person in the state.

Justice StewART: Constitutionally as you know there are many, many decisions that say that county action is state action from the point of view of the Fourteenth Amendment.

MR. WRIGHT Yes, for some purposes, they are. But whether they are for purposes of the equal protection clause in this kind of sense, there I would say our decisions are to the contrary. They say that to have things different in one county than it is in another county is not a violation of the equal protection clause.

JUSTICE BRENNAN: I am just curious. On district power equalizations, what about the percentage of ratings? Do they not differ in Texas? They seem to, everywhere else. Some places assess at 30 percent and some at 80 and some at 100.

Mr. Wright: They differ very widely in Texas, as they do in most states, Justice Brennan. And I think that if a state were to adopt district power equalizing, it, as a practical matter, would have to adopt statewide assessing. I do not see any other way in which the scheme would be feasible. Otherwise you simply use a favorable rate and you get more than you are entitled to. And I think that demonstrates the further incursion on local government that the ideas presented here by the appellees represent that very little is to be left of local government if the decision below is affirmed.

We contend [thus] that if we are subject only to the rational basis test, that this is not one of those cases in which we must demonstrate a compelling state interest in order to justify the results for which we argue and justify the state plan.

Later the Court moves on to deliberating with Mr. Gochman who is representing the public school children (appellees). Justice Rehnquist engages Gochman with a direct question attempting to explore the consequences of a power equalization system. With this type of intervention, Justice Rehnquist seemed compelled to teach a short lesson about the irony of such an alternative system in public education. 
JUSTICE REHNQUIST: [Mr. Gochman] you say if you went to power equalization Edgewood would have the opportunity to get itself out of the situation? If it chose not to get out of it - the State-it would not be free to make that choice? Did you not just say to me that it would still, if it chose not to, the choice would itself be a violation of equal protection? Did you say that?

With these questions the Court sought clarification while providing a lesson on consistency and fairness before proceeding to the question of which standard of review (Kunsch, 1994) then is required in the case. Freedom of choice is suggested as a fundamental right.

Mr. Gochman: No. If the compelling interest of local control is that strong, they you could have that kind of discrimination; that the people in an area can decide for themselves whether they want to lock themselves into a poor school system.

JUSTICE REHNQUIST: What is your position on that question about the compelling interest? I mean that is really the question. Would it be constitutional, or would it not, for Edgewood to have the opportunity but chooses not to exercise it?

MR. GOCHMAN: I would think it would be constitutional.

JUSTICE REHNQUIST: In effect, your theory makes the districts equal, but may leave the students utterly unequal?

Justice Rehnquist's point implicitly raises the issue of race (as in the Brown case) because of the composition of the poor school district in Edgewood (96\% racial minorities), which the Court later dismisses as not relevant to reaching their decision, however.

Mr. Gochman: Yes. But it would have a different basis, at least. It would not lock onto the poor as it does now. And, mobility is a serious factor in this case. If this were a rich guy in a poor district, we would not be in court. He would just move. But the poor had no way out of the present system.

This deliberative engagement with the Justices at the head of the national seminar in oral argument seemed rooted in a concern for broader understanding of social meanings. Yet, the Court focused more on sustaining the "will" of the people by making sure to reveal the significance of equality as a fundamental value but from a more conservative pro-local collective choice perspective.

\section{Conclusion}

After exploring the U.S. Supreme Court's educative role historically, theoretically and textually, and especially in light of current debates about who should be appointed by President Donald Trump, at least two points should be considered: First, the Supreme Court has a constitutional obligation through its power of 
judicial review and as a "co-equal" institution to contribute substantively to the larger policy debates within an American democratic environment characterized in deliberative and pluralist terms. Second, the Court's lesser known educative role should be accepted during oral arguments when internal deliberation matters prior to the Court's public pronouncements on policy controversies.

To this extent, three assumptions need to be made explicit-one empirical and the last two normative: (1) the U.S. democratic order is underwritten by a constitutional system guided by a written Constitution, which itself provides a warrant for the various institutional roles of the Supreme Court, (2) political actors, citizens, and scholars should take the Court's adjudicating processes, especially during oral arguments, seriously to the extent that managing, maintaining, and controlling a large multifaceted society within a complex constitutional order actually matters, and (3) that those personally involved in litigation, in legislating along with resolving constitutional disputes and broader social and political disagreements, should appreciate the importance of equality, fairness and ethics as fundamental values worth pursuing and protecting for sustaining democratic life.

Yet, scholars have long argued that the Court has been an anti-democratic institution because of its counter-majoritarian nature. However, I showed in this article that moving the debate away from considering the Court's place within majoritarian system to instead a pluralist deliberative one makes room for a 'coequal' institutional partner; thus allowing Justices to use judicial review as an instrument for carrying out important broader constitutional functions, including an educative role. To this end, I tried to move beyond traditional theoretical and normative debates about judicial review's place in U.S. politics. Instead, I explored the "national seminar" metaphor differently and focused on the Court's work during oral arguments in two separate cases that invoked the Equal Protection Clause of the $14^{\text {th }}$ Amendment, and less on the impact of final decisions on social norms and liberal democratic life.

Finally, since at least the mid-twentieth century, the U.S. Supreme Court has instructed and guided in order to protect the dignity and integrity of individual citizens through its concerns for civil rights and liberties, with various exceptions. In this article, I found that in order to justify an institutional egalitarian argument, we have to consider different modes of interpretation, or the methods of textual interpretation used by each justice to determine the meaning of their reason-based questions (ethical or otherwise) during oral argument. This has to be considered in order to assess whether or not the Court does possess a consistent educative function prior to any legal pronouncements. Last, this study reveals that there are occasions when the Court's educative role-with the "question" as a teaching device guiding deliberations - becomes necessary to not only maintaining ethical standards during oral arguments but also sustaining a broader vital pluralist democratic system. 


\section{References}

Abraham, H. J. (1994). The judiciary: The Supreme Court in the governmental process $\left(9^{\text {th }}\right.$ Ed.). Madison, WI: Brown \& Benchmark Publishers.

Abraham, H. J., \& Perry, B. A. (2003). Freedom \& The Court: Civil rights and liberties in the United States $\left(8^{\text {th }}\right.$ Ed). Lawrence, Kansas: University of Kansas Press.

Ackerman, B. (1991). We the People foundations. Cambridge, MA: Harvard University Press.

Araiza, W., Haddon, P. A., \& Roberts, D. E. (2006). Constitutional law: Cases, history, and dialogues. LexisNexis.

Besson, S., \& Marti, J. L. (Eds.) (2006). Deliberative democracy and its discontents. Aldershot, Burlington: Ashgate.

Bickel, A. (1968). The least dangerous branch: The Supreme Court at the bar of politics ( $2^{\text {nd }}$ Ed.). New Haven, CT: Yale University Press.

Brennan, Jr., W. J. (1972). Inside view of the High Court. In L. W. Levy (Ed.), The Supreme Court under Earl Warren. New York, NY: Quadrangle Books.

Brinkley, A. (1993). The affluent society, the unfinished nation: A concise history of the American people. New York, NY: Alfred A. Knopf.

Brown v. Board of Education. (1954). 347 U.S. 483.

Dahl, R. (1957). Decision-Making in a democracy: The Supreme Court as a national policy-maker. Journal of Public Law, 6(1957), 279-295.

Davis, A. L., \& Graham, B. L. (1995). The Supreme Court, race, and civil rights: From Marshall to Rehnquist. Thousand Oaks, CA: Sage Publications.

Eisgruber, C. (1962). Is the Supreme Court an educative institution? New York University Law Review, 961(1962).

Ely, J. H. (1980). Democracy and distrust: A theory of judicial review. Cambridge, MA: Harvard University Press.

Epstein, L., Knight, J., \& Martin, A. (2001). The Supreme Court as a strategic national policymaker. Emory Law Journal, 50, 583-611.

Figueroa, C. (2014). Book Foreword (Politics). In T. Broadwick, You're not listening and other plays (pp. ix-xi). Southlake, TX: Fountainhead Press.

Fisher, L. (1999). American constitutional law (3 ${ }^{\text {rd }}$ Ed.). Durham, N.C.: Caroline Academic Press.

Friedman, L. (1969). Argument: The oral argument before the Supreme Court in Brown v. Board of Education of Topeka, 1952-1955. New York, NY: Chelsea House Publishers. 
Frisch, M. J., \& Stevens, R. G. (1973). Felix Frankfurter (1882-1965). The political thought of American statesmen: Selected writings and speeches. Illinois: F. E. Peacock Publishers.

Funston, R. (1978). A vital national seminar: The Supreme Court in American political life. Palo Alto, California: Mayfield Publishing Company.

Gambitta, R. A. (1992). San Antonio Independent School District v. Rodriguez. In K. L. Hall (Ed.) The Oxford Companion to the Supreme Court of the United States (pp. 753-754). Oxford University Press.

Gammon, T. E. (1977). Equal protection of the law and San Antonio Independent School District V. Rodriguez. Valparaiso University Law Review, 11(3), $435-472$.

Goldstein, L. F. (1987). Judicial review and democratic theory: Guardian Democracy vs. Representative Democracy. Western Political Quarterly, 40(3), September, 391-412.

Guitton, S., \& Irons, P. (1993). May it please the court: The most significant oral arguments made before the Supreme Court since 1955. New York, NY: New Press.

Hollinger, D. A. (1979). Historians and the discourse of intellectuals. In J. Higham, \& P. K. Conkin (Eds.), New directions in American intellectual history (pp. 42-63). Baltimore, MD: Johns Hopkins University Press.

Hugh, W. (2002). Five types of legal arguments. Durham, NC.

Keynes, E. (1991). Democracy, judicial review, and the war powers. Undeclared war: Twilight zone of constitutional power. University Park, PA: Penn State Press.

Kunsch, K. (1994). Standard of review (state and federal): A primer. Seattle University Law Review, 18(11), 11-49.

Landynski, J. W. (1982). Fundamental Individual Rights and Public Policy in the New Supreme Court (The Annual Paley Lectures in American Civilization). Jerusalem: The Magnus Press, The Hebrew University of Jerusalem.

Landynski, J. W., \& Padover, S. K. (1983). The living U.S. constitution ( $2^{\text {nd }}$ Ed.). New York, NY: New American Library.

Levinson, S. (2000). Preface to Third Edition. In R. G. McCloskey (Ed.). The American Supreme Court (pp. ix-xi). University of Chicago Press.

Marsh, D., Ercan, S. A., \& Furlong, P. (2017). A skin, not a sweater: Ontology and epistemology in Political Science. In V. Lowndes, D. Marsh, $\&$ G. Stoker, Theory and methods in political science $\left(4^{\text {th }}\right.$ Ed.) (pp. 177198). London: Palgrave.

Marti, J. L. (2017). Pluralism and consensus in deliberative democracy. Critical Review of International Social and Political Philosophy, 20(5), 556-579.

McCloskey, R. (2000). American Supreme Court. University of Chicago Press. 
Mouffe, C. (1999). Deliberative democracy or agonistic pluralism? Social Research, 66(3), 745-758.

Mouffe, C. (2005). The return of the political. London and New York: Verso Books.

O'Brien, D. (2003). Constitutional Law and politics: Civil rights and liberties, (vol. 2, $5^{\text {th }}$ Ed.). New York, NY: W. W. Norton \& Company.

Perreti, T. J. (1999). Whither the court and constitution? In Defense of a Political Court (pp. 229-230). Princeton University Press.

Powell, H. J. (1985). The original understanding of original intent. Harvard Law Review, 98(5), 885-948.

Rakove, J. N. (1996). Original meanings: Politics and Ideas in the making of the constitution. New York, NY: Alfred A. Knopf.

Rakove, J. N. (Eds.). (1990). Interpreting the constitution: The debate over original intent. Boston, MA: Northeastern University Press.

Reed, Jr., A. (2004). Beyond Black, White and Brown: A Forum. The Nation April 15.

Report of the Study Group on the Caseload of the Supreme Court, 57 F.R.D. (1972), p. 573.

Rosenberg, G. N. (1993). The hollow hope: Can courts bring about social change. University of Chicago Press.

Rostow, E. V. (1952). The democratic character of judicial review. Harvard Law Review, 66, 193-224.

San Antonio Independent School District v. Rodriguez. (1973). 411 U.S. 1.

Schmitter, P. C., \& Lynn Karl, T. (1996). What democracy is... and is not. In L. Diamond \& M. F. Plattner (Eds.), The global resurgence of democracy. Baltimore, MD: Johns Hopkins University Press.

Smith, R. M. (1997). Civic ideals: Conflicting visions of citizenship in U.S. history. Yale University Press.

Sunstein, C. (1993). The partial constitution. Cambridge, MA: Harvard University Press.

Thayer, J. B. (1893). The origin and scope of the American doctrine of constitutional law. Harvard Law Review, 7(3), October 25, 130-156.

The Philadelphia Inquirer. (1968, October 4).

The Supreme Court of the United States, October 1971 Term, No. 71-1332, Red Books.

Thompson, D. F. (2008). Deliberative democratic theory and empirical political science. Annual Review of Political Science, 11, 497-520.

Tushnet, M. (1999). Taking the constitution away from the courts. Princeton University Press.

United States v. Carolene Products Co. (1939). 304 U.S. 144. 
Voeten, E. (2014, September 12). Judges as principled politicians. The Washington Post.

Whittington, K. E. (2009). Political foundations of judicial supremacy: The presidency, the Supreme Court, and constitutional leadership in U.S. History. Princeton University Press.

Zinn, H. (1995). A people's history of the United States. New York: HarperCollins. 